\title{
Advanced Reactor Fuels Irradiation Experiment Design Objectives
}

Fuel Cycle Research \& Development

Heather J.M. Chichester Steven L. Hayes Douglas Dempsey Jason M. Harp

Prepared for U.S. Department of Energy Advanced Fuels Campaign

Revision 0 September 16, 2016 FCRD-FUEL-2016-000031 


\section{DISCLAIMER}

This information was prepared as an account of work sponsored by an agency of the U.S. Government. Neither the U.S. Government nor any agency thereof, nor any of their employees, makes any warranty, expressed or implied, or assumes any legal liability or responsibility for the accuracy, completeness, or usefulness, of any information, apparatus, product, or process disclosed, or represents that its use would not infringe privately owned rights. References herein to any specific commercial product, process, or service by trade name, trade mark, manufacturer, or otherwise, does not necessarily constitute or imply its endorsement, recommendation, or favoring by the U.S. Government or any agency thereof. The views and opinions of authors expressed herein do not necessarily state or reflect those of the U.S. Government or any agency thereof. 


\section{Advanced Reactor Fuels Irradiation Experiment Design Objectives}

Heather J. M. Chichester, Steven Hayes,

Douglas Dempsey, Jason M. Harp

September 2016

Idaho National Laboratory

Idaho Falls, Idaho 83415

http://www.inl.gov

Prepared for the

U.S. Department of Energy

Office of Nuclear Energy

Under DOE Idaho Operations Office

Contract DE-AC07-05ID14517 
INTENTIONALLY BLANK 


\section{EXECUTIVE SUMMARY}

This report summarizes the objectives of the current irradiation testing activities being undertaken by the Advanced Fuels Campaign relative to supporting the development and demonstration of innovative design features for metallic fuels in order to realize reliable performance to ultra-high burnups. The AFC3 and AFC-4 test series are nearing completion; the experiments in this test series that have been completed or are in progress are reviewed and the objectives and test matrices for the final experiments in these two series are defined. The objectives, testing strategy, and test parameters associated with a future AFC test series, AFC-5, are documented. Finally, the future intersections and/or synergies of the AFC irradiation testing program with those of the TREAT transient testing program, emerging needs of proposed Versatile Test Reactor concepts, and the Joint Fuel Cycle Study program's Integrated Recycle Test are discussed. 


\section{CONTENTS}

EXECUTIVE SUMMARY

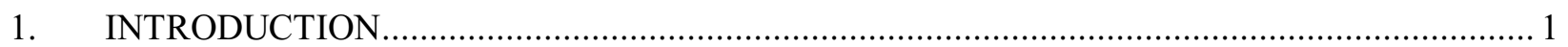

1.1 Advanced Fuel Concept Description and Benefits .................................................... 1

1.2 Advanced Fuels Experiment Variables ......................................................................... 2

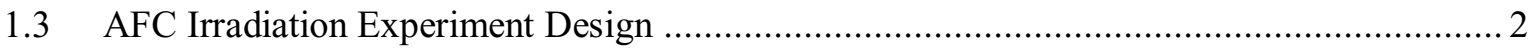

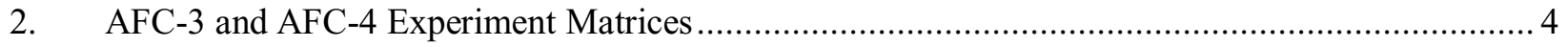

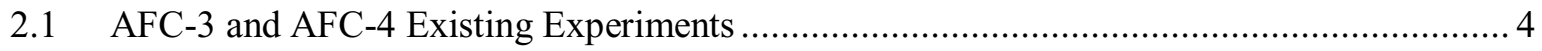

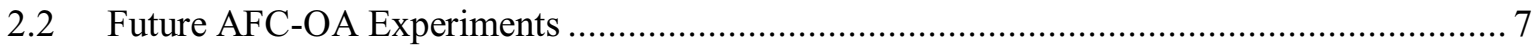

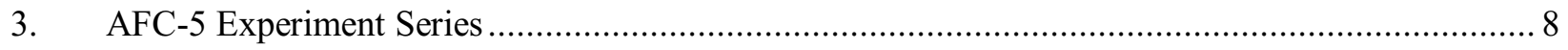

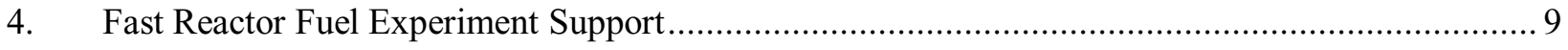

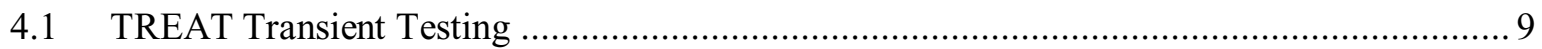

$4.2 \quad$ Versatile Test Reactor Driver Fuel Support.................................................................. 9

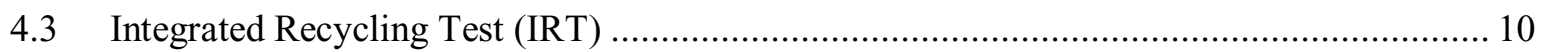

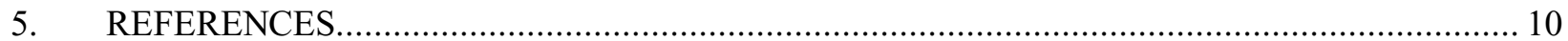

\section{FIGURES}

Figure 1. AFC Outboard A Experiment Schematic .................................................................. 3

Figure 2. AFC Outboard A Cross-Section showing Rodlet, Capsule, and Basket ................................. 4

\section{TABLES}

Table 1. Variables and Levels Considered for Irradiation Testing.......................................................2

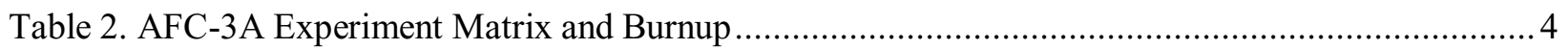

Table 3. AFC-3B Experiment Matrix and Burnup ............................................................................... 5

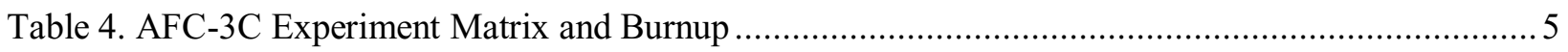

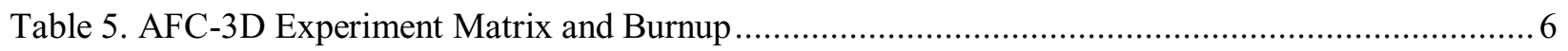

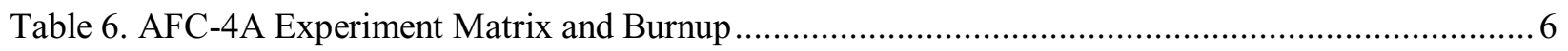

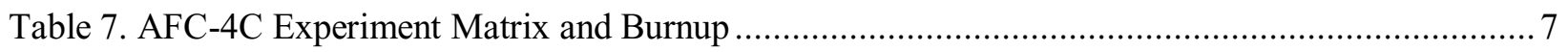

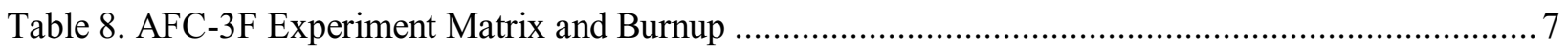

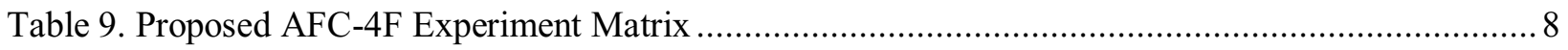


INL/EXT-16-39923, Rev 0 


\section{ACRONYMS}

$\begin{array}{ll}\text { AFC } & \text { Advanced Fuels Campaign } \\ \text { ATR } & \text { Advanced Test Reactor } \\ \text { EBR-II } & \text { Experimental Breeder Reactor II } \\ \text { FCCI } & \text { Fuel Cladding Chemical Interaction } \\ \text { HM } & \text { Heavy Metal } \\ \text { INL } & \text { Idaho National Laboratory } \\ \text { IRT } & \text { Integrated Recycling Test } \\ \text { MA } & \text { Minor Actinides } \\ \text { PIE } & \text { Postirradiation Examination }\end{array}$


INTENTIONALLY BLANK 


\section{ADVANCED REACTOR FUELS IRRADIATION EXPERIMENT DESIGN OBJECTIVES}

\section{INTRODUCTION}

Metallic fuels have a history of use that spans the entire nuclear age, from the early plutonium production reactors (1940s) and the first liquid metal fast breeder reactors (1950s) to the most advanced reactor designs of today. Initially, metallic fuels were employed for their ease of fabrication and high heavy metal density (which led to the most favorable breeding efficiencies in fast reactors). During subsequent decades, metallic fuel technology matured significantly, leading to the realization of major benefits in fuel reliability and burnup, proliferation-resistant recycling, remote fabrication, and passive reactor safety. Such characteristics make metallic fuels a highly competitive technology, especially for use in sodium fast reactors.

This unparalleled legacy notwithstanding, a suite of design innovations, originally included as part of a competitive Advanced Fuels Campaign (AFC) solicitation for innovative, ultra-high burnup fuels, have been proposed having the potential to deliver multifold advances in fuel reliability and performance, actinide utilization, and fabrication efficiency, while retaining all the historic benefits of the metallic fuel system. Selected features have been incorporated in the AFC irradiation experiment series, AFC-3 and AFC-4. This report summarizes the features in existing experiments, defines the test matrix for the AFC4F experiment, and identifies the direction for future experiment series, e.g., AFC-5.

\subsection{Advanced Fuel Concept Description and Benefits}

Key features of the historic metallic fuel system are: 1) a metallic alloy fuel (U-Pu-Am-Np-Zr) at 75\% smeared density to accommodate fuel swelling, 2) sodium-bonded to low-swelling ferritic-martensitic stainless steel cladding to keep fuel temperatures low, and 3) incorporating a large plenum to accommodate high gas release. Metallic fuel design innovations originally proposed included [1]:

- Decreased fuel smeared density. Further reduction of the fuel smeared density, to an appropriate level below $75 \%$, to allow for the accommodation of swelling to ultra-high burnups without cladding strain from fuel-cladding mechanical interaction. The reference path would retain the sodium bond. A proposed parallel research path would investigate annular metallic fuel, perhaps metallurgically bonded to the cladding, thus eliminating the need for sodium bond [2], leading to a somewhat smaller plenum volume and a reduction in waste hazard associated with sodium disposal.

- Coating or liner on cladding inner diameter. Use of a cladding coating or liner to act as a diffusion barrier to mitigate fuel-cladding chemical interaction [3].

- Vented fuel pin. Venting the released fission gases and helium from the fuel pin into the primary reactor coolant to maintain cladding stresses at low levels to high burnup [2]. This innovation will also decrease plant capital cost due to a significant reduction in reactor vessel height.

- U-Mo based alloy fuel system. The uranium-zirconium based alloy fuel system suffers from phase separations in the composition and temperature ranges relevant to fast reactor fuel conditions. Those phase separations drive fuel constituent redistribution during irradiation, resulting in low-zirconium (and thus reduced solidus) regions within the fuel. Transition to the uranium-molybdenum based alloy fuel system should eliminate this phenomenon and the fuel thermal margin constraints it imposes and should also increase the fuel thermal conductivity and solidus temperature [4]. The drawback to the U-Mo fuel alloy is an expected increase in fuel- 
cladding chemical interaction with stainless steel claddings, so realization of this design innovation may be predicated on finding an acceptable cladding coating or liner.

- Targeted fuel alloy additions. Major lanthanide fission products migrate to the fuel-cladding interface and react with the stainless steel cladding, increasingly thinning the cladding and reducing its load-bearing capability. Targeted, minor alloy additions that will chemically bind with the lanthanides and immobilize them in the fuel matrix, thus preventing their transport to the fuel-cladding interface, are under investigation [5].

- Advanced fabrication method. Metallic fuels have traditionally been fabricated using casting processes. As an alternative to casting, fabrication of the metallic fuel alloy by extrusion promises several benefits [6]: 1) up to $100 \%$ utilization of each fuel ingot, dramatically reducing process waste; 2) elimination of volatile constituent losses during fabrication; and 3) possible coextrusion of fuel and cladding in the case of an annular fuel design.

- Fuel recycle. All of the proposed innovations must retain complete compatibility with the historic electrochemical recycle scheme.

\subsection{Advanced Fuels Experiment Variables}

Several variables have been identified to evaluate the concepts presented in Section 1.1. Some variables have multiple options; a selection of variables and options are included in Table 1. Combining all variables and options would result in a very large test matrix. Based on existing research reported in the literature and expert engineering judgment, those variables and conditions with the most likely positive impact on high burnup were selected for initial irradiation testing.

Table 1. Variables and Levels Considered for Irradiation Testing

\begin{tabular}{|c|c|c|c|c|c|c|}
\hline 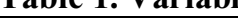 & 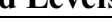 & 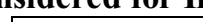 & & & & \\
\hline Fuel & $\begin{array}{l}\text { Fuel } \\
\text { Alloy }\end{array}$ & $\begin{array}{c}\text { Geometry / } \\
\text { Bond }\end{array}$ & $\begin{array}{c}\text { Smear } \\
\text { Density } \\
(\%)\end{array}$ & $\begin{array}{c}\text { Alloy } \\
\text { Additions }\end{array}$ & $\begin{array}{l}\text { Burnup } \\
(\% \mathrm{HM})\end{array}$ & Cladding \\
\hline $\mathrm{U}$ & $\mathrm{Zr}$ & Solid / Na & 55 & & $8-10$ & HT-9 \\
\hline $\mathrm{U}+\mathrm{Pu}$ & Mo & Annular / & 65 & & $15-20$ & liner \\
\hline $\mathrm{U}+\mathrm{Pu}+\mathrm{MA}$ & MTZ & $\mathrm{He}$ & 75 & $P d$ & $30-40$ & coating \\
\hline
\end{tabular}

Initial experiments for high-burnup fuel development focused on U-based fuels, $\mathrm{Zr}$ and Mo fuel alloys, decreased smear density, comparison of solid and annular geometries, and fuel additives to immobilize lanthanide fission products in the fuel matrix [7].

\subsection{AFC Irradiation Experiment Design}

The irradiation experiment vehicle design was based on previous transmutation fuel experiments conducted in the Advanced Test Reactor (ATR) at INL. The experiment consists of a miniature fuel rod, designated a rodlet, contained inside an outer capsule which provides the safety boundary for the experiment [8]. A schematic of the rodlet and capsule design is shown in Figure 1; a cross-section of the experiment, is shown in Figure 2. Five capsules are stacked vertically inside an experiment basket and inserted into ATR. The basket contains a thin layer of cadmium to substantially harden the neutron spectrum seen by the test rodlet, resulting in a fuel temperature profile that is essentially prototypic of that experienced by fuels in an actual fast reactor. 
The experiments are irradiated in any of four (4) Outboard A positions in the ATR, hence the experiment design is known as the AFC-OA experiment. The AFC-3 and AFC-4 series of experiments used this design. Individual experiment matrices are given unique identifiers, for example, AFC-3A, AFC-3B, etc.

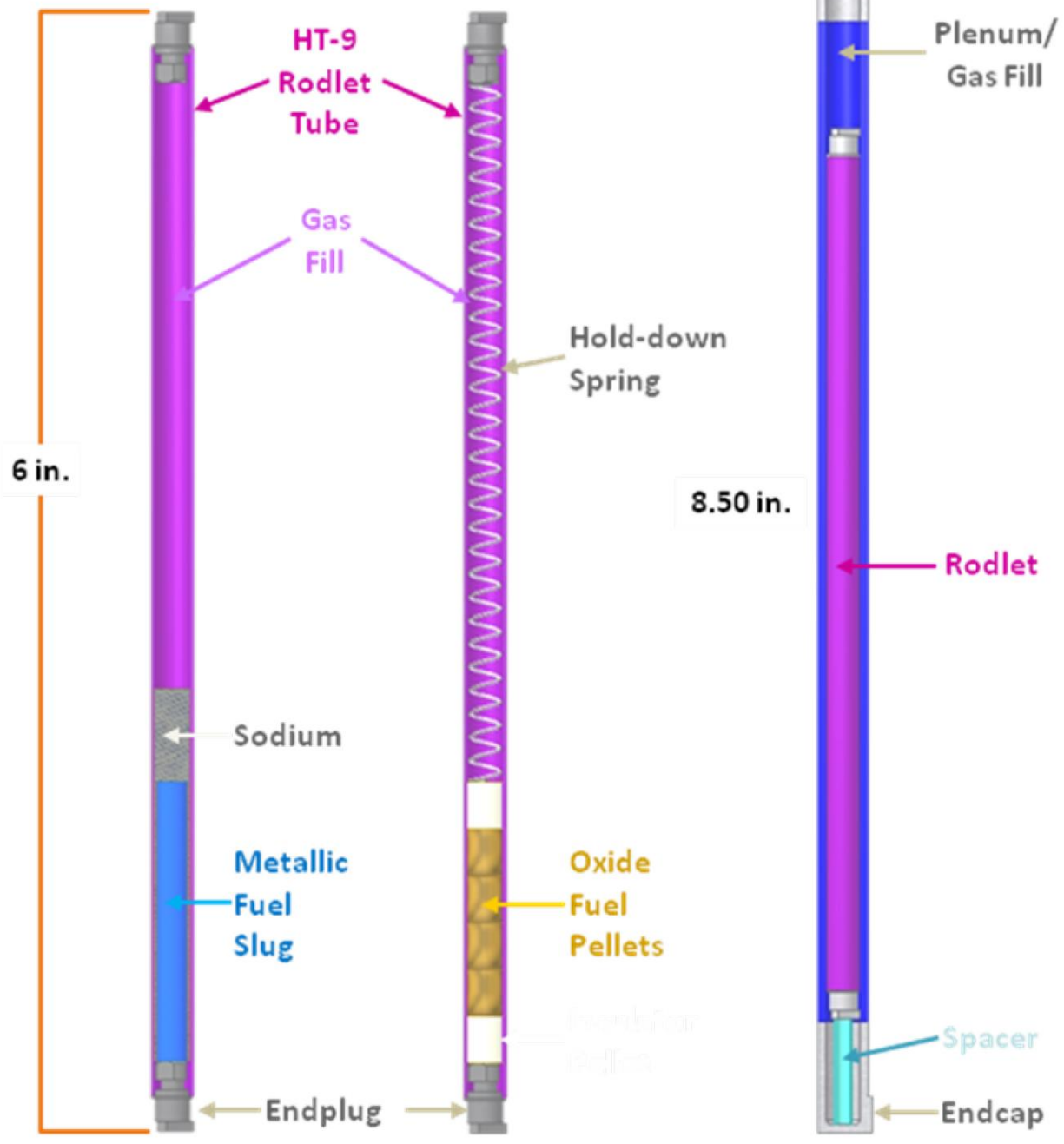

Figure 1. AFC Outboard A Experiment Schematic 


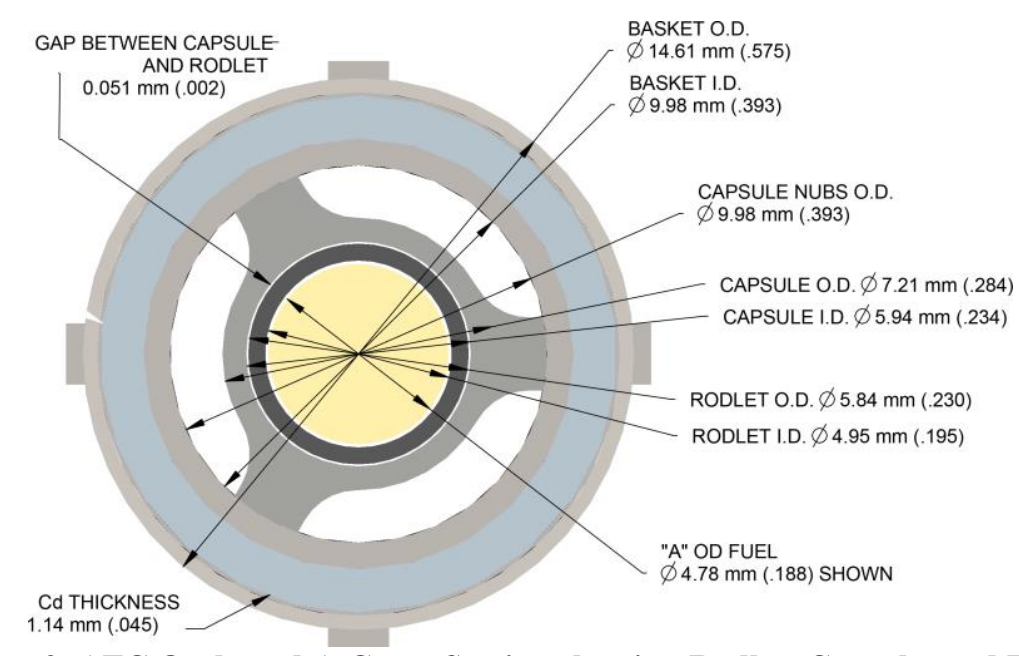

Figure 2. AFC Outboard A Cross-Section showing Rodlet, Capsule, and Basket

\section{AFC-3 AND AFC-4 EXPERIMENT MATRICES}

From the fuel design variables discussed in Section 1.1 and shown in Table 1, a set of variables and conditions were selected for the initial experiments. With ultra-high burnup as a goal of these experiments, selecting fuel design options with the best probability for success and starting a long-term irradiation test were key goals. At the same time, creating a short-term irradiation test to provide early feedback on key features of interest through postirradiation examination (PIE) was important. Details of the AFC-3 and AFC-4 experiments are described in the following sections.

\subsection{AFC-3 and AFC-4 Existing Experiments}

Experiments AFC-3A and AFC-3B were designed, fabricated, and began irradiation in parallel. AFC-3A was designated as the shorter-duration, early feedback experiment, and $\mathrm{AFC}-3 \mathrm{~B}$ as the longer-term, high burnup experiment. The nominal experiment matrices for AFC-3A and 3B are shown in Table 2 and Table 3, respectively. Irradiation began in October 2011. During irradiation, problems with the uniformity and concentricity of the experiment capsule tubes were discovered. The program chose to end the irradiation early, initiate PIE, and fabricate replacement experiments.

Table 2. AFC-3A Experiment Matrix and Burnup

\begin{tabular}{|c|c|c|c|c|c|c|c|c|c|}
\hline & \multirow[b]{2}{*}{ Capsule } & \multirow[b]{2}{*}{ Rodlet } & \multicolumn{3}{|c|}{$\mathrm{AFC}-3 \mathrm{~A} \uparrow$} & \multicolumn{4}{|c|}{$\begin{array}{c}\text { AFC-3A } \\
\text { EOC 151B 121 EFPD }\end{array}$} \\
\hline & & & Composition & Geometry & SD & $\begin{array}{c}\text { Average } \\
\text { LHGR } \\
\text { (W/cm) }\end{array}$ & $\begin{array}{l}\text { Fission } \\
\text { Density } \\
\left(\mathrm{f} / \mathrm{cm}^{3}\right)\end{array}$ & ${ }^{235} \mathrm{U}$ (at.\%) & HM (at.\%) \\
\hline 1 & $3 \mathrm{~A}-\mathrm{C} 1$ & 3A-R1 & U-10Mo & solid & $75 \%$ & 353 & $8.96 \mathrm{E} 20$ & 3.94 & 2.31 \\
\hline 2 & $3 \mathrm{~A}-\mathrm{C} 2$ & 3A-R2 & U-10Mo & annular & $55 \%$ & 362 & $1.26 \mathrm{E} 21$ & 8.04 & 3.31 \\
\hline 3 & $3 \mathrm{~A}-3$ & & Materials Test & & & & & & \\
\hline 4 & 3A-C4 & 3A-R4 & $\mathrm{U}-10 \mathrm{Zr}$ & annular & $55 \%$ & 328 & $1.14 \mathrm{E} 21$ & 9.46 & 3.18 \\
\hline 5 & $3 \mathrm{~A}-\mathrm{C} 5$ & 3A-R5 & $\begin{array}{l}\text { U-1Pd-10Zr } \\
\text { U-2Pd-10Zr }\end{array}$ & solid & $55 \%$ & $\begin{array}{l}368 \\
337\end{array}$ & $\begin{array}{l}9.51 \mathrm{E} 20 \\
8.77 \mathrm{E} 20\end{array}$ & $\begin{array}{l}5.89 \\
5.44\end{array}$ & $\begin{array}{l}2.51 \\
2.47\end{array}$ \\
\hline
\end{tabular}

AFC-3A inserted cycle 150B, 15 Oct 2011; discharged cycle 151B (mid), 25 Mar 2012; 121 EFPD [9,10,11].

$\dagger$ Alloy composition expressed in weight percent. 
Table 3. AFC-3B Experiment Matrix and Burnup

\begin{tabular}{|c|c|c|c|c|c|c|c|c|c|}
\hline \multirow{2}{*}{\multicolumn{2}{|c|}{ Capsule }} & \multirow[b]{2}{*}{ Rodlet } & \multicolumn{3}{|c|}{$\mathrm{AFC}-3 \mathrm{~B} \dagger$} & \multicolumn{4}{|c|}{$\begin{array}{c}\text { AFC-3B } \\
\text { EOC 151B 121 EFPD }\end{array}$} \\
\hline & & & Composition & Geometry & SD & $\begin{array}{c}\text { Average } \\
\text { LHGR } \\
(\mathrm{W} / \mathrm{cm})\end{array}$ & $\begin{array}{l}\text { Fission } \\
\text { Density } \\
\left(\mathrm{f} / \mathrm{cm}^{3}\right)\end{array}$ & ${ }^{235} \mathrm{U}$ (at.\%) & HM (at.\%) \\
\hline 1 & 3B-C1 & 3B-R1 & $\mathrm{U}-4 \mathrm{Pd}-10 \mathrm{Zr}$ & solid & $55 \%$ & 260 & $9.09 \mathrm{E} 20$ & 4.20 & 2.65 \\
\hline 2 & 3B-C2 & 3B-R2 & $\mathrm{U}-4 \mathrm{Pd}-10 \mathrm{Zr}$ & annular & $55 \%$ & 344 & $1.21 \mathrm{E} 21$ & 8.55 & 3.57 \\
\hline 3 & & & Dummy & & & & & & \\
\hline 4 & 3B-C4 & 3B-R4 & U-10Mo & solid & $55 \%$ & 286 & $9.65 \mathrm{E} 20$ & 9.22 & 2.44 \\
\hline 5 & $3 \mathrm{~B}-\mathrm{C} 5$ & 3B-R5 & U-10Mo & solid & $55 \%$ & 275 & $9.36 \mathrm{E} 20$ & 6.09 & 2.36 \\
\hline
\end{tabular}

AFC-3B inserted cycle 150B, 15 Oct 2011; discharged cycle 151B (mid), 25 Mar 2012; 121 EFPD [9,10,11].

$\dagger$ Alloy composition expressed in weight percent.

The AFC-3C and AFC-3D experiments were designed as replacement experiments for AFC-3A and AFC-3B, respectively. Minor changes were made to the experiment matrices based on feedback from the previously-fabricated and characterized fresh fuel from 3C and 3D. In particular, the Zr alloy content was increased in the Pd-containing compositions to offset a small quantity of $\mathrm{Zr}$ that segregates with $\mathrm{Pd}$ when it added to the fuel alloy, taking it out of solution in the bulk fuel matrix. The AFC-3C and 3D experiment matrices and burnup are show in Table 4 and Table 5, respectively.

AFC-3C and 3D were discharged from ATR before their targeted burnup based on indications of higher than expected reactor power levels during irradiation. Calculated experiment temperatures, based on the reported experiment powers, indicated a potential over-heating of the experiments. The calculated temperatures for AFC-3D capsules 1 and 4 were within acceptable ranges and those capsules remained in ATR for additional irradiation.

Table 4. AFC-3C Experiment Matrix and Burnup

\begin{tabular}{|c|c|c|c|c|c|c|c|c|c|}
\hline & \multirow[b]{2}{*}{ Capsule } & \multirow[b]{2}{*}{ Rodlet } & \multicolumn{3}{|c|}{$\mathrm{AFC}-3 \mathrm{C} \uparrow$} & \multicolumn{4}{|c|}{$\begin{array}{c}\text { AFC-3C } \\
\text { EOC 157C 115 EFPD }\end{array}$} \\
\hline & & & Composition & Geometry & $\mathrm{SD}$ & $\begin{array}{c}\text { Average } \\
\text { LHGR } \\
(\mathrm{W} / \mathrm{cm})\end{array}$ & $\begin{array}{l}\text { Fission } \\
\text { Density } \\
\left(\mathrm{f} / \mathrm{cm}^{3}\right)\end{array}$ & HM (at.\%) & ${ }^{235} \mathrm{U}$ (at.\%) \\
\hline 1 & $3 \mathrm{C}-\mathrm{C} 1$ & 3C-R1 & U-10Mo & solid & $75 \%$ & 388 & 8.82 E20 & 2.32 & 3.88 \\
\hline 2 & $3 \mathrm{C}-\mathrm{C} 2$ & 3C-R2 & U-10Mo & annular & $55 \%$ & 435 & $1.21 \mathrm{E} 21$ & 3.21 & 8.31 \\
\hline 3 & $3 \mathrm{C}-\mathrm{C} 3$ & 3C-R3 & U-10Zr & solid & $65 \%$ & 413 & $9.70 \mathrm{E} 20$ & 2.79 & 9.49 \\
\hline 4 & $3 \mathrm{C}-\mathrm{C} 4$ & 3C-R4 & U-10Zr & annular & $55 \%$ & 423 & $1.18 \mathrm{E} 21$ & 3.35 & 9.39 \\
\hline 5 & $3 \mathrm{C}-\mathrm{C} 5$ & 3C-R5 & $\begin{array}{l}\mathrm{U}-1 \mathrm{Pd}-13 \mathrm{Zr} \\
\mathrm{U}-2 \mathrm{Pd}-13 \mathrm{Zr}\end{array}$ & solid & $75 \%$ & $\begin{array}{l}452 \\
428\end{array}$ & $\begin{array}{l}8.90 \mathrm{E} 20 \\
8.37 \mathrm{E} 20\end{array}$ & $\begin{array}{l}2.83 \\
2.69\end{array}$ & $\begin{array}{l}6.00 \\
5.69\end{array}$ \\
\hline
\end{tabular}

AFC-3C inserted cycle 154B, 23 Aug 2013; discharged cycle 157C, 18 Feb 2015; 115 EFPD [12,13,14].

$\dagger$ Alloy composition expressed in weight percent. 
Table 5. AFC-3D Experiment Matrix and Burnup

\begin{tabular}{|c|c|c|c|c|c|c|c|c|c|}
\hline & \multirow[b]{2}{*}{ Capsule } & \multirow[b]{2}{*}{ Rodlet } & \multicolumn{3}{|c|}{$\mathrm{AFC}-3 \mathrm{D} \dagger$} & \multicolumn{4}{|c|}{$\begin{array}{c}\text { AFC-3D } \\
\text { EOC 158B 194.7 EFPD }\end{array}$} \\
\hline & & & Composition & Geometry & $\mathrm{SD}$ & $\begin{array}{c}\text { Average } \\
\text { LHGR } \\
(\mathrm{W} / \mathrm{cm})\end{array}$ & $\begin{array}{l}\text { Fission } \\
\text { Density } \\
\left(\mathrm{f} / \mathrm{cm}^{3}\right)\end{array}$ & HM (at.\%) & ${ }^{235} \mathrm{U}$ (at.\%) \\
\hline 1 & 3D-C1 & 3D-R1 & $\mathrm{U}-10 \mathrm{Zr}$ & annular & $55 \%$ & 297 & $1.61 \mathrm{E} 21$ & 4.59 & 6.79 \\
\hline 2 & $3 \mathrm{D}-\mathrm{C} 2$ & 3D-R2 & U-4Pd-13Zr & solid & $55 \%$ & 330 & $8.38 \mathrm{E} 20$ & 2.75 & 5.95 \\
\hline 3 & $3 \mathrm{D}-\mathrm{C} 3$ & 3D-R3 & U-10Mo & solid & $55 \%$ & 322 & $8.41 \mathrm{E} 20$ & 2.19 & 6.78 \\
\hline 4 & 3D-C4 & 3D-R4 & U-10Mo & annular & $55 \%$ & 305 & $1.69 \mathrm{E} 21$ & 4.64 & 14.04 \\
\hline 5 & 3D-C5 & 3D-R5 & U-4Pd-13Zr & annular & $55 \%$ & 349 & 8.97 E20 & 2.94 & 4.81 \\
\hline
\end{tabular}

AFC-3D inserted cycle 154B, 23 Aug 2013; 3D-C2, C3, C5 discharged cycle 157A, 30 Aug 2014, 91.1 EFPD; 3D-C1, C4 discharged cycle 158B, 2016, 194.70 EFPD [12,15,16,17].

$\dagger$ Alloy composition expressed in weight percent.

The AFC-4A experiment design included variations on the fuel alloy composition, as shown in Table 6. U-Mo and U-Zr compositions were included in previous AFC-3 experiments, but the addition of MTZ (5Mo-4.3Ti-0.7Zr) was new in AFC-4A. MTZ is proposed as a candidate fuel alloy combination to take advantages of the benefits of both $\mathrm{Zr}$ and Mo in metallic fuel. Based upon published future ATR power projections, AFC-4A was designed at a reactor power of 16MW and began irradiation in November 2013. Subsequently, future reactor power projections were increased to $18 \mathrm{MW}$ which would have caused the experiment to exceed maximum operating temperatures. This resulted in the decision to remove AFC-4A from irradiation testing before meeting the burnup target.

Table 6. AFC-4A Experiment Matrix and Burnup

\begin{tabular}{|c|c|c|c|c|c|c|c|c|c|}
\hline & \multirow[b]{2}{*}{ Capsule } & \multirow[b]{2}{*}{ Rodlet } & \multicolumn{3}{|c|}{$\mathrm{AFC}-4 \mathrm{~A} \dagger$} & \multicolumn{4}{|c|}{$\begin{array}{c}\text { AFC-4A } \\
\text { EOC 157D 121.2 EFPD }\end{array}$} \\
\hline & & & Composition & Geometry & SD & $\begin{array}{c}\text { Average } \\
\text { LHGR } \\
(\mathrm{W} / \mathrm{cm})\end{array}$ & $\begin{array}{l}\text { Fission } \\
\text { Density } \\
\left(\mathrm{f} / \mathrm{cm}^{3}\right)\end{array}$ & HM (at.\%) & ${ }^{235} \mathrm{U}($ at. $\%)$ \\
\hline 1 & 4A-C1 & 4A-R1 & U-10Mo & annular & $65 \%$ & 335 & $9.47 \mathrm{E} 20$ & 2.41 & 3.55 \\
\hline 2 & 4A-C2 & 4A-R2 & Dummy & & & & & & \\
\hline 3 & $4 \mathrm{~A}-\mathrm{C} 3$ & 4A-R3 & U-5Mo-4.3Ti-0.7Zr & solid & $75 \%$ & 353 & $8.79 \mathrm{E} 20$ & 2.51 & 8.16 \\
\hline 4 & $4 \mathrm{~A}-\mathrm{C} 4$ & 4A-R4 & U-2Pd-5Mo-4.3Ti-0.7Zr & solid & $75 \%$ & 359 & $8.88 \mathrm{E} 20$ & 2.55 & 7.42 \\
\hline 5 & 4A-C5 & 4A-R5 & U-10Zr & solid & $75 \%$ & 366 & $8.96 \mathrm{E} 20$ & 2.51 & 4.67 \\
\hline
\end{tabular}

AFC-4A inserted cycle 155A, 8 Nov 2013; discharged cycle 157D, 12 Aug 2015; 121.2 EFPD. [13,14,18].

$\dagger$ Alloy composition expressed in weight percent.

Additional fuel alloy variations are included in the AFC-4C experiment to investigate the performance of different alloys and to further assess the ability of $\mathrm{Pd}$ as an alloy addition to immobilize lanthanide fission products in the fuel matrix and mitigate fuel-cladding chemical interaction. The AFC-4C experiment matrix and current burnup status are shown in Table 7. 
Table 7. AFC-4C Experiment Matrix and Burnup

\begin{tabular}{|c|c|c|c|c|c|c|c|c|c|}
\hline \multirow{2}{*}{\multicolumn{2}{|c|}{ Capsule }} & \multirow[b]{2}{*}{ Rodlet } & \multicolumn{3}{|c|}{$\mathrm{AFC}-4 \mathrm{C} \dagger$} & \multicolumn{4}{|c|}{$\begin{array}{c}\text { AFC-4C } \\
\text { EOC 158B 51.4 EFPD }\end{array}$} \\
\hline & & & Composition & Geometry & SD & $\begin{array}{l}\text { Average } \\
\text { LHGR } \\
(\mathrm{W} / \mathrm{cm})\end{array}$ & $\begin{array}{l}\text { Fission } \\
\text { Density } \\
\left(\mathrm{f} / \mathrm{cm}^{3}\right)\end{array}$ & HM (at.\%) & ${ }^{235} \mathrm{U}$ (at.\%) \\
\hline 1 & $4 \mathrm{C}-\mathrm{C} 1$ & 4C-R1 & $\mathrm{U}-10 \mathrm{Zr}$ & annular & $65 \%$ & 295 & $3.92 \mathrm{E} 20$ & 1.12 & 2.218 \\
\hline 2 & 4C-C2 & 4C-R2 & U-4Ta-6Zr & solid & $75 \%$ & 314 & 3.43 E20 & 0.87 & 4.06 \\
\hline 3 & 4C-C3 & $4 \mathrm{C}-\mathrm{R} 3$ & U-5Mo-4.3Ti-0.7Zr & solid & $75 \%$ & 307 & $3.29 \mathrm{E} 20$ & 0.92 & 5.00 \\
\hline 4 & 4C-C4 & $4 \mathrm{C}-\mathrm{R} 4$ & U-2Pd-5Mo-4.3Ti-0.7Zr & solid & $75 \%$ & 293 & $3.13 \mathrm{E} 20$ & 0.96 & 4.67 \\
\hline 5 & 4C-C5 & 4C-R5 & $\mathrm{U}-10 \mathrm{Zr}$ & solid & $75 \%$ & 317 & $3.35 \mathrm{E} 20$ & 0.92 & 2.93 \\
\hline
\end{tabular}

AFC-4C inserted cycle 158B 10 Feb 2016; target burnup 8-10 at.\% HM [17].

$\dagger$ Alloy composition expressed in weight percent.

\subsection{Future AFC-OA Experiments}

The AFC-OA experiment series continues with an experiment recently delivered to ATR and with plans for future experiments. The AFC-3F experiment contains newly-fabricated (by arc-casting) U-10Zr and $\mathrm{U}-20 \mathrm{Pu}-10 \mathrm{Zr}$ fuel slugs along with fuel slugs previously fabricated using the EBR-II injection casting furnace; the text matrix is shown in Table 8. Unirradiated $\mathrm{U}-10 \mathrm{Zr}$ and $\mathrm{U}-20 \mathrm{Pu}-10 \mathrm{Zr}$ fuel slugs were retrieved from EBR-II archives and sections to length for the AFC-3F experiment. These archive U-10Zr and $\mathrm{U}-20 \mathrm{Pu}-10 \mathrm{Zr}$ fuel segments were encapsulated and included as part of the AFC-3F rodlet/capsule experiment.

One objective of this experiment is to allow a direct comparison of traditional metallic fuels that were extensively irradiated in EBR-II (and FFTF) under prototypical fast reactor conditions and identical fuels irradiated in ATR using cadmium filters to create a modified epi-thermal environment. Using archive fuel fabricated for EBR-II, but irradiated in ATR, eliminates any fabrication variables and allows for a direct comparison between of fuel performance data from identical fuels irradiated in EBR-II and in the cadmium-shrouded ATR spectrum.

A second objective of this experiment is to directly compare historic and current fabrication processes (i.e., injection casting vs. arc-casting) and determine if there is any difference on fuel performance. The same fuel compositions, U-10Zr and U-20Pu-10Zr, archive EBR-II fuel fabricated by injection casting and newly prepared fuel fabricated by arc-casting, will be irradiated under nominally identical compositions. Results obtained from PIE will allow an assessment of any differences in fuel performance introduced by the different fabrication methods.

Table 8. AFC-3F Experiment Matrix and Burnup

\begin{tabular}{|c|c|c|c|c|c|}
\hline \multirow{2}{*}{\multicolumn{2}{|c|}{ Capsule }} & \multirow{2}{*}{ Rodlet } & \multicolumn{3}{|c|}{$\mathrm{AFC}-3 \mathrm{~F} \dagger$} \\
\hline & & & Composition & Geometry & SD \\
\hline 1 & $3 \mathrm{~F}-\mathrm{C} 1$ & 3F-R1 & U-10Zr (EBR-II) & solid & $75 \%$ \\
\hline 2 & $3 \mathrm{~F}-\mathrm{C} 2$ & $3 F-R 2$ & $\mathrm{U}-10 \mathrm{Zr}$ & solid & $75 \%$ \\
\hline 3 & $3 \mathrm{~F}-\mathrm{C} 3$ & 3F-R3 & U-20Pu-10Zr & solid & $75 \%$ \\
\hline 4 & $3 \mathrm{~F}-\mathrm{C} 4$ & $3 \mathrm{~F}-\mathrm{R} 4$ & $\mathrm{U}-10 \mathrm{Zr}$ & solid & $75 \%$ \\
\hline 5 & $3 \mathrm{~F}-\mathrm{C} 5$ & $3 F-R 5$ & U-20Pu-10Zr (EBR-II) & solid & $75 \%$ \\
\hline
\end{tabular}

AFC-3F inserted cycle 160A, Aug 2016; target burnup 8-10 at.\% HM.

$\dagger$ Alloy composition expressed in weight percent. 
A new irradiation experiment, AFC-4F, is planned for FY 2018. The proposed AFC-4F experiment matrix is shown in Table 9. One objective of this experiment is to add lanthanide (i.e., rare earth; RE) elements to the fuel alloy during fabrication to simulate possible carryover of lanthanide fission products during electro-chemical recycle of metallic fuel and test the ability of coatings, liners, and fuel alloy additives to mitigate fuel-cladding chemical interaction.

Another objective of the AFC-4F experiment is to extend the fuel system to compositions containing Pu. Previous AFC-series experiments (AFC-1 and AFC-2) contained Pu as a primary component of developing and examining transmutation fuel concepts. Previous AFC-3 and AFC-4 experiments employed the simpler $U$ alloy system to investigate the feasibility of innovative features proposed for high-burnup applications (e.g., low fuel smear density; annular, Na-free fuel forms; additives to immobilize lanthanide fission products) and provided a less complex fabrication path at the initial, scoping phase of investigation. Since the testing on $\mathrm{U}$ alloys has proven promising, adding $\mathrm{Pu}$ to the fuel provides now will provide more realistic transmutation fuel compositions and yield more relevant fuel performance data.

Table 9. Proposed AFC-4F Experiment Matrix

\begin{tabular}{|c|l|l|l|}
\hline Experiment & \multicolumn{1}{|c|}{$\begin{array}{c}\text { Nominal Composition } \\
(\mathrm{wt} \%)\end{array}$} & \multicolumn{1}{|c|}{ Coatings/Liners } & \multicolumn{1}{|c|}{$\begin{array}{c}\text { Geometry / } \\
\text { Bond }\end{array}$} \\
\hline $4 \mathrm{~F}-1$ & $\mathrm{U}-20 \mathrm{Pu}-10 \mathrm{Zr}-3 \mathrm{RE}$ & $\mathrm{Zr}$ (sheath) & solid / Na \\
\hline $4 \mathrm{~F}-2$ & $\mathrm{U}-20 \mathrm{Pu}-10 \mathrm{Zr}-3 \mathrm{RE}$ & $\mathrm{TiN}$ & solid / Na \\
\hline $4 \mathrm{~F}-3$ & $\mathrm{U}-20 \mathrm{Pu}-10 \mathrm{Zr}-3 \mathrm{RE}$ & $\mathrm{Cr}$ (supplied by KAERI) & solid / Na \\
\hline $4 \mathrm{~F}-4$ & $\begin{array}{l}\mathrm{U}-20 \mathrm{Pu}-10 \mathrm{Zr}-3 \mathrm{RE} \text { or } \\
\mathrm{U}-10 \mathrm{Zr}-3 \mathrm{RE}\end{array}$ & $\begin{array}{l}\text { Zr or V } \\
\text { (Zr strongly preferred, apply on fuel OD) }\end{array}$ & annular / He \\
\hline $4 \mathrm{~F}-5$ & $\mathrm{U}-20 \mathrm{Pu}-10 \mathrm{Zr}-x \mathrm{Pd}-3 \mathrm{RE}$ & No liner; add Pd to fuel matrix & solid / Na \\
\hline
\end{tabular}

The target conditions for the AFC-4F experiment include $75 \%$ smear density, $600^{\circ} \mathrm{C}$ peak inner cladding temperature, and 8-10 at.\% HM burnup.

\section{AFC-5 EXPERIMENT SERIES}

The AFC experiments are planned to be an on-going series of experiments to investigate and quantify the benefits of new fuel alloys; reduced smear density, annular fuel slugs; fuel alloy additions to immobilize lanthanide fission products; liners and coatings to mitigate fuel-cladding chemical interaction; and other possible features to realize reliable performance of metallic fuels to ultra-high burnup (both with and without the inclusion of minor actinides for a possible transmutation mission). The AFC-3 and AFC-4 experiments currently in progress or to be included in the near term (AFC-3F and AFC-4F, outlined in Section 2.2, and IRT which is discussed in Section 4.3) will occupy all available ATR Outboard A positions until approximately FY 2020, so the test matrix for future experiments (designated for the AFC5 test series) does not have to be finalized for several years, and waiting to begin developing the specifics of those tests will allow results from current and future postirradiation examinations to be included in that planning process. Nonetheless, the direction of the test program and its objectives are expected to be a natural extension of the test program of the past several years. Specifically recommendations for future experiments are expected to include an assessment of the suite of innovative design features with an extension to metallic fuel systems that include $\mathrm{Pu}$ and minor actinides (to support a possible actinide transmutation mission).

- Fuel alloy systems: Zr and MTZ (recent results have shown unacceptable fuel-cladding interaction behavior in the U-Mo system, so additional testing of this feature is currently suspended)

- Fuel geometry/Bond: solid/Na, annular/He 
- Fuel smear density: $75 \%, 65 \%, 55 \%$

- Fuel additives: Pd for lanthanide fission product immobilization (and potentially other candidate additives for this purpose that may be identified NEUP projects currently underway), Ta for increasing fuel solidus

- Cladding coatings and liners: $\mathrm{Zr}, \mathrm{V}, \mathrm{Cr}, \mathrm{TiN}$

- Burnup (at.\% HM): 8-10 (nominal burnup, allows comparison to existing fuel performance database), 15-20 (high burnup, where effect of lanthanide fission product immobilization and/or cladding diffusion barriers become important), 30-40 (ultra-high burnup goal)

- Experiments with RE elements added during fabrication to simulate accelerated burnup and/or effects due to recycle and to test fuel additives and/or cladding coatings and liners. If these design features are successful in mitigating fuel-cladding chemical interaction, testing of metallic fuels to higher temperatures (i.e., peak cladding temperatures in the $600-650^{\circ} \mathrm{C}$ range) will become possible and necessary.

The Advanced Fuels Campaign is engaged in developing, advancing, and demonstrating metallic fuel technology for a variety of possible missions that could be undertaken using advanced reactor systems. This does not represent a down-selection to metallic fuel forms exclusively, but is rather a decision to focus on making meaningful advances in the area of metallic fuel technology given current funding constraints. Select irradiation experiments have been conducted on the oxide fuel system (e.g., AFC-2C and AFC-2D) and fundamental oxide fuel studies continue within the campaign, primarily in support of international collaborations.

\section{FAST REACTOR FUEL EXPERIMENT SUPPORT}

\subsection{TREAT Transient Testing}

The TREAT transient test reactor is expected to become operational in the FY 2018 timeframe. Although initial transient testing campaigns are expected to be centered around the enhanced, accident tolerant fuel concepts under development by the Advanced Fuels Campaign and its commercial partners, windows of opportunity for testing metallic fuels will eventually become available. Early transient testing of metallic fuels will almost certainly be performed on unirradiated fuels, progressing to irradiated fuels. Numerous fuel pins irradiated in EBR-II and FFTF have been retained for transient testing, and it is expected that these fuels will be incorporated into a future TREAT testing program. These legacy metallic fuels are very important for transient testing for two primary reasons: 1) they were irradiated under prototypic fast reactor conditions, and 2) they represent much longer fuel pins, nearing lengths relatively prototypic of future commercial fast reactors (in the case of FFTF fuel pins). However, in general these legacy metallic fuel pins available for transient testing do not include fuels with minor actinides or with any of the advanced, innovative features currently under investigation. For this reason, it will likely be necessary to develop an AFC series of irradiation tests designed to produce irradiated rodlets with these innovative features for eventual transient testing in TREAT.

\subsection{Versatile Test Reactor Driver Fuel Support}

DOE is currently evaluating concepts for a versatile test reactor that would serve a variety of needs, including delivering a high fast neutron flux (of at least $4 \times 10^{15} \mathrm{n} / \mathrm{cm}^{2}-\mathrm{sec}$ ) for fuels and materials experiments. Both Idaho National Laboratory (INL) and Argonne National Laboratory (ANL) have developed preliminary concepts for such a versatile test reactor $[19,20]$. 
Both the INL and ANL concepts propose to use metallic fuels for their respective test reactor driver fuels, although both concepts include some deviations from the historic metallic fuel design most widely used in the Experimental Breeder Reactor II (EBR-II) and qualified for use in the Fast Flux Test Facility (FFTF) prior to its shutdown (namely sodium-bonded, $75 \%$ smear density, U-10Zr metallic fuel). In order to provide a very high fast neutron flux from a small test reactor core constrained to use a driver fuel with $<20 \%$ enriched uranium, analyses supporting these versatile test reactor concepts have found that it may be necessary to reduce the zirconium content of the fuel below $10 \%$, increase the fuel smear density above $75 \%$, and/or incorporate plutonium into the fuel alloy. All of these deviations have some existing data from prior irradiation experiments to inform designers, although additional information may be needed to support a safety case needed for licensing.

Since multiple fuel concepts are still under evaluation, it would seem premature to initiate a supporting irradiation testing campaign at present. However, as these (and perhaps other) conceptual designs mature, and a DOE down-selection process is developed, it may be necessary to perform some irradiation experiments to inform that process. In anticipation of that eventuality, an irradiation test series (perhaps designated as VTR) is expected to be incorporated into the long term AFC irradiation testing strategy when appropriate.

\subsection{Integrated Recycling Test (IRT)}

As part of DOE's cooperative research and development agreement with the Korean Atomic Energy Research Institute (KAERI), the Joint Fuel Cycle Study (JFCS) program is planning to irradiate a metallic fuel experiment (designated IRT) fabricated remotely using actual transuranic feed materials recovered from the electrochemical recycle of LWR spent fuel. While this experiment will be entirely funded by the JFCS Campaign, the goals of this demonstration are entirely synergistic with those of the Advanced Fuels Campaign in the area of transmutation fuel development. Furthermore, IRT will make use of the existing AFC-OA test train design and be irradiated in an ATR Outboard-A position. For this reason, it is necessary that the AFC irradiation testing strategy reflect the IRT experiment since there is some overlap in reactor test space utilization between the two DOE programs.

\section{REFERENCES}

1 A.E. Wright, S.L. Hayes, T.H. Bauer, H.J. Chichester, G.L. Hofman, J.R. Kennedy, T.K. Kim, Y.S. Kim, R.D. Mariani, W.D. Pointer, A.M. Yacout, D. Yun, "Development of Advanced Ultra-High Burnup SFR Metallic Fuel Concept - Project Overview," Transactions of the American Nuclear Society, Vol. 106 (2012), pp 1102-1105.

2 W. N. Beck, R. J. Fousek, and J. H. Kittel, "The Irradiation Behavior of High-Burnup UraniumPlutonium Alloy Prototype Fuel Elements," ANL-7388, May 1968. (See also B. Kryger, "Contribution a L'etude du Degagement des Gaz de Fission danes les Combustibles Nucleaires Metalliques," Rapport CEA-R-3888, October 1969).

3 J. I. Cole, R. Fielding, "Cladding Liner Development for GNEP Transmutation Fuels," Trans. Am. Nucl. Soc., Vol. 99 (2008) pp. 307-308.

4 Y.S. Kim, G.L. Hofman, A.M. Yacout, T.K. Kim, "An Assessment of the Use of U-Pu-Mo Fuel in Fast Reactors," International Conference on Fast Reactors and Related Fuel Cycles (FR09), Challenges and Opportunities - December 7-11, 2009, Kyoto, Japan, IAEA-CN-176.

5 Y.S. Kim, G.L. Hofman, A.M. Yacout, "Migration of Minor Actinides and Lanthanides in Fast Reactor Metallic Fuel," J. Nucl. Matl., Vol. 392 (2009), pp. 164-170. 
6 R. Fielding, J. Jue, J. Stuart, “Zirconium Metal Inert Matrix Fuel Fabrication,” Trans. Am. Nucl. Soc., Vol. 94 (2006) pp. 742-743.

7 H.J.M. Chichester, R.D. Mariani, S.L. Hayes, J.R. Kennedy, A.E. Wright, Y.S. Kim, A.M. Yacout, G.L. Hofman, "Advanced Metallic Fuel for Ultra-High Burnup: Irradiation Tests in ATR,"

Transactions of the American Nuclear Society, Vol. 106 (2012), pp 1349-1531.

8 K. Barrett, "Project Execution Plan for the Fuel Cycle Research and Development AFC-OA Irradiation Experiments in the ATR," PLN-3608 Rev. 4, January 2013.

9 C.R. Glass, G.S. Chang, "ATR Cycle 151A Projected Physics Evaluations for the AFC-3A and -3B Experiments in the A-10 and A-11 Positions," ECAR-1757, December 8, 2011.

10 C.R. Glass, G.S. Chang, "ATR Cycle 151A As-run and 151B Projected Physics Evaluations for the AFC-3A and -3B Experiments in the A-10 and A-11 Positions," ECAR-1816, February 22, 2012.

11 C.R. Glass, G.S. Chang, "ATR Cycle 151B As-run Physics Evaluations for the AFC-3A and -3B Experiments in the A-10 and A-11 Positions," ECAR-2128, April 4, 2012.

12 M. A. Lillo, "ATR Cycle 155A Projected Physics Analysis for the AFC-3C, AFC-3D, AFC-4A, and AFC-4B Experiments Irradiated in the ATR A-10, A-11, A-09, and A-12 Outboard A Positions," ECAR-2409, November 5, 2013.

13 M. A. Lillo, "ATR Cycle 155B Projected and 155A As-Run Physics Analysis for the AFC Experiments Irradiated in the ATR A-10, A-11, A-09, and A-12 Outboard A Positions," ECAR-2450, January 30, 2014.

14 M. A. Lillo, "ATR Cycle 157D Projected Physics Analysis for the AFC Experiments Irradiated in the ATR Outboard A Positions," ECAR-2897, May 22, 2015.

15 M. A. Lillo, "ATR Cycle 157C Projected Physics Analysis for the AFC Experiments Irradiated in the ATR Outboard A Positions,” ECAR-2756, January 27, 2015.

16 M. A. Lillo, "ATR Cycle 158B Projected Physics Analysis for the AFC Experiments Irradiated in the ATR Outboard A Positions," ECAR-3147, February 2, 2016.

17 E.T. Swain, "ATR Cycle 160A Projected Physics Analysis for the AFC Experiments Irradiated in the ATR Outboard A Positions," ECAR-3392, August 30, 2016.

18 M. A. Lillo, "ATR Cycle 158A Projected Physics Analysis for the AFC Experiments Irradiated in the ATR Outboard A Positions," ECAR-3056, October 28, 2015.

19 G. Youinou, et al., VCTR: A Versatile Coupled Test Reactor Concept, Idaho National Laboratory Report, INL-EXT-16-38852, May 2016.

20 C. Grandy, et al., FASTER Test Reactor, Argonne National Laboratory Report, ANL-ART-40, January 2016. 